\title{
Ida Fink idzie do szkoły
}

\begin{abstract}
Ida Fink Goes to School
Aвstract: In the text, the author takes a closer look at Ida Fink's symbolic "return" to school. The writer, who had to abandon her studies in piano at the Lwów Conservatoire as a result of the Third Reich's attack on the USSR in 1941, since the end of 1990s has been a frequent presence on Polish school curricula and exams. The essay analyses the very manner in which her works appear within the school canon, student's books, as well as the Matura examination sheets. What is more, some of the rudimentary biographical mistakes and simplifications are reviewed in the text. Ida Fink's case analysis also formed a basis for a wider glance at the evolution of the Shoah theme's presence in Polish school.
\end{abstract}

KeY wORDs: Shoah, Ida Fink, education, high school, Polish language, the Matura exam

Ida Fink - izraelska pisarka polskiego pochodzenia lub twórczyni literatury polskiej w Izraelu, jak na przykład proponuje Karolina Famulska-Ciesielska ${ }^{1}-$ jest jedną $\mathrm{z}$ tych autorek, do których dorobku chętnie sięga się $\mathrm{w}$ edukacji polonistycznej na poziomie szkolnym. Nie tylko zresztą w Polsce. Jej opowiadania regularnie trafiają do kanonu tekstów szkolnych w Izraelu, Niemczech czy

* Fragmenty tego szkicu zostały wcześniej wykorzystane w tekstach: Twórczość Idy Fink jako problem maturalny. „Polonistyka” 2014, nr 11, s. 16-18 oraz Matura z Zagłady. W: Auschwitz $i$ Holokaust. Edukacja w szkole i w miejscu pamięci. Red. P. Trojański. Oświęcim 2014, s. 125-137. Oba zostały zmienione.

${ }^{1}$ Autorka w swojej książce roztrząsa różne warianty nazewnicze tego nurtu, odnosząc się np. do propozycji „wielojęzyczna literatura żydowska” (M. Adamczyk-Garbowska) lub „trzeci stan skupienia" obok literatury krajowej i emigracyjnej (J. Leociak). Zob. K. FAMULSKA-CiESIELSKa: Polacy, Żydzi, Izraelczycy. Tożsamość w literaturze polskiej w Izraelu. Toruń 2008, s. 29-41. 
Stanach Zjednoczonych. Utwory Fink tłumaczone były na kilkanaście języków, między innymi na: angielski, duński, francuski, hebrajski, hiszpański, holenderski, niemiecki, norweski, słowacki, węgierski czy włoski. W 2017 roku ukazał się przekład jej Podróży na język ukraiński, w 2018 roku zbioru opowiadań Odpływający ogród na rosyjski. Monika Adamczyk-Garbowska słusznie zauważa, że swoją popularność zawdzięcza pisarka również formule prozy: „Ważne są także względy praktyczne, bowiem opowiadania Idy Fink - krótkie, zwarte, klarowne, nierzadko opatrzone wyraźną tezą - stanowią idealne utwory do zamieszczania w antologiach i wykorzystywania w programach kursów uniwersyteckich"2. W archiwum autorki w Bibliotece Narodowej Izraela w Jerozolimie znaleźć można rysunki wysyłane jej z różnych krajów przez dzieci, które najwyraźniej głęboko przeżyły lekturę jej opowiadań. Tym, co odróżnia jednak analizowanie twórczości Idy Fink w Polsce od innych miejsc na świecie, jest fakt, że wszystkie swoje utwory pisała po polsku i mimo iż ponad pół wieku mieszkała w Izraelu, nadal posługiwała się przede wszystkim językiem ojczystym ${ }^{3}$.

Urodziła się 11 stycznia 1921 roku w Zbarażu (Wołyń) w rodzinie żydowskiej jako córka Ludwika Landaua, lekarza, i Franciszki z domu Stein, nauczycielki biologii i wicedyrektorki gimnazjum w Zbarażu. W tej zresztą szkole - Państwowym Gimnazjum Humanistycznym im. Henryka Sienkiewicza w Zbarażu - Fink uczyła się i w 1938 roku zdała egzamin maturalny. Następnie podjęła studia pianistyczne w Konserwatorium Polskiego Towarzystwa Muzycznego we Lwowie, przerwane w czerwcu 1941 roku z powodu ataku Niemiec na ZSRR. To właśnie wtedy zakończyła edukację, której po wojnie nie była już w stanie kontynuować4. Można powiedzieć, że wówczas skończyła się jej dosłowna „droga do szkoły”, lecz wracała do niej niejednokrotnie za pośrednictwem swoich utworów.

Latem 1941 roku Ida Fink powróciła do Zbaraża, tam w 1942 roku zmuszona była przenieść się do getta, skąd jesienią tegoż roku uciekła wraz z siostrą przez Tarnopol do Lwowa. W 1943 roku wyjechały obie na tzw. aryjskich papierach na roboty do Trzeciej Rzeszy (pracowały między innymi w fabryce i w gospodarstwie rolnym). Po zakończeniu wojny, wiosną 1945 roku pisarka przebywała

${ }^{2}$ M. Adamczyk-Garbowska: Pisarze $z$,innej” Europy - kilka uwag o recepcji literatury polsko-żydowskiej w Stanach Zjednoczonych. W: Literatura polsko-żydowska. Studia i szkice. Red. E. Prokop-Janiec, S. Żurek. Kraków 2011, s. 239.

${ }^{3}$ Podobnie własną eseistykę postrzegał np. Ryszard Löw, który pisał: „Szkice te były pisane w Izraelu. Z tego tytułu - z mocy stałego przebywania tutaj ich autora oraz jego identyfikacji należą one do izraelskiego piśmiennictwa w języku polskim. I są one zarazem znakiem obecności tego piśmiennictwa w wielkim i granic geograficznych nie posiadającym »gospodarstwie polskiej literatury«, jak nazwał to Czesław Miłosz. Powstały one z długoletnich zaciekawień literackimi sprawami polsko-żydowskimi i polsko-izraelskimi oraz niezmiennej fascynacji polskością i Polską" (R. Löw: Znaki obecności. O polsko-hebrajskich i polsko-żydowskich związkach literackich. Kraków 1995, s. 5).

${ }^{4}$ Jak wspominała w rozmowie ze mną jej siostra Hela, na skutek prac, które wykonywała pisarka w czasie okupacji, nie miała już tak sprawnych rąk, by po wojnie wrócić do koncertowania. 
w obozie UNRRA w Ettlingen. W 1946 roku wróciła do Polski - początkowo zamieszkała w Kłodzku, gdzie jej ojciec był ordynatorem szpitala. W 1948 roku wyszła za mąż za Brunona (Bronisława) Finka, inżyniera, pianistę i taternika (zm. 1983). Na początku lat 50. osiedli razem we Wrocławiu. Tam w 1952 roku urodziła się ich córka Miri. W latach 1954-1955 pisarka pracowała jako akompaniatorka w Wyższej Szkole Wychowania Fizycznego we Wrocławiu; krótko była też związana z Polskim Radiem, dla którego przygotowywała reportaże. W 1957 roku wyemigrowała wraz z rodziną do Izraela i zamieszkała w Cholonie. W latach 1960-1971 pracowała w Instytucie Jad Waszem (w dziale gromadzenia świadectw osób ocalałych z Holokaustu), a w latach 1971-1983 jako bibliotekarka w dziale muzycznym biblioteki Instytutu Goethego w Tel Awiwie. Pisarce nie dane było skończyć edukacji na poziomie, który spełniłby jej oczekiwania, choć właściwie całe życie była z nauczaniem związana. Do późnej emerytury udzielała na przykład lekcji gry na pianinie.

Opowiadania i fragmenty prozy Ida Fink publikowała między innymi w polskojęzycznej prasie w Izraelu. Za swoją twórczość otrzymała wiele prestiżowych wyróżnień. W 1995 roku została uhonorowana nagrodą Buchmanna Instytutu Jad Waszem, a w 1996 włoską nagrodą literacką Premio Moravia. W 2003 roku otrzymała Nagrodę Specjalną Polskiego PEN Clubu, w 2004 roku doktorat honoris causa Uniwersytetu Ben-Guriona w Beer Szewie, wreszcie w 2008 roku Pras Izrael (państwową Nagrodę Izraela). Jej nazwisko znalazło się na ogłoszonej przez National Yiddish Book Center w Nowym Jorku liście stu najważniejszych autorów żydowskich. Zmarła 27 września 2011 roku w Tel Awiwie.

Swoistym paradoksem jest, że Ida Fink nie doczekała się kompleksowego omówienia swojej twórczości, nie mówiąc o monografii ${ }^{5}$. Uznana została przez metodyków i nauczycieli za klasyka, weszła do szkolnego kanonu, a jednocześnie nie analizowano tego dorobku, poświęciwszy mu w Polsce, Izraelu czy Stanach Zjednoczonych zaledwie kilkanaście ważnych tekstów.

W niniejszym szkicu chciałbym się przyjrzeć obecności jej utworów w edukacji szkolnej, przy okazji czyniąc z tego pretekst do rozważań o przemianach realizacji tematyki Zagłady w szkole w ciągu ostatnich trzydziestu lat.

${ }^{5}$ Po niemiecku ukazała się jedynie skromna, nieroszcząca sobie prawa do opisania całej twórczości pisarki książka Agnieszki RząDCY: Foto-Grafie. Fotografische Narrativität im Werk von Ida Fink. München 2012. Utworom Idy Fink poświęcono również kilka niepublikowanych prac doktorskich. 


\section{Ida Fink w kanonie}

Symboliczna droga Idy Fink do polskiej szkoły zaczęła się na dobre pod koniec lat 90. W czasach PRL-u nie było w szkolnej edukacji w ogóle miejsca dla zagłady Żydów, nawet wtedy, kiedy omawiano utwory Nałkowskiej, Borowskiego czy Moczarskiego, bezpośrednio jej dotyczące. Szerzej o owym „kanonie, który nie powstał", pisała choćby Sylwia Karolak ${ }^{6}$.

Pierwszą jaskółką zmian było minimum programowe z 1992 roku, które weszło w życie na mocy zarządzenia nr 23 ministra edukacji narodowej z dnia 18 sierpnia 1992 roku. Określało ono podstawowe treści merytoryczne oraz umiejętności dla wszystkich przedmiotów ogólnokształcących nauczanych na kolejnych etapach edukacyjnych - i na etapie ponadpodstawowym w klasie czwartej liceum przewidziano duży dział zatytułowany „Literatura okresu II wojny światowej i powojenna”. Wśród utworów epickich znalazły się w nim Wybrane opowiadania Tadeusza Borowskiego, Poczatek Andrzeja Szczypiorskiego, Rozmowy $z$ katem Kazimierza Moczarskiego czy Zdązyć przed Panem Bogiem Hanny Krall. Jak słusznie podkreśla w nieopublikowanej rozprawie doktorskiej Kategoria Zagłady w szkolnym dyskursie polonistycznym po roku 2009 (na przykładzie prozy Idy Fink i Irit Amiel) Agnieszka Kasperek: „Krall i Szczypiorski (pisarze podejmujący problem Zagłady w swoich dziełach) nie pojawili się w szkole okresu PRL"7. Następna zmiana, a więc podstawa programowa z 1995 roku, nie wprowadziła do nauczania języka polskiego w szkole podstawowej tematyki Zagłady. W punkcie „Przykład pamiętnika, dziennika, reportażu" jako lekturę obowiązkową umieszczono za to Kamienie na szaniec Aleksandra Kamińskiego. Z kolei na etapie licealnym proponowano między innymi Wybrane opowiadania Tadeusza Borowskiego, zniknął natomiast tekst Hanny Krall (Zarządzenie nr 8 MEN z dn. 15 maja 1997 roku).

Prawdziwa rewolucja edukacji nastąpiła w 1999 roku, kiedy ośmioklasową szkołę podstawową, czteroletnie liceum i pięcioletnie technikum zastąpiły sześcioklasowa szkoła podstawowa, trzyletnie gimnazjum i trzyletnie liceum oraz czteroletnie technikum. 15 lutego 1999 roku weszło w życie rozporządzenie ministra edukacji narodowej w sprawie podstawy programowej kształcenia ogólnego ${ }^{8}$, która wprowadzała obowiązek nauczania o Holokauście w gimnazjum

${ }^{6}$ Zob. S. Karolak: Doświadczenie Zagłady w literaturze polskiej 1947-1991. Kanon, który nie powstat. Poznań 2014.

7 A. KASPEREK: Kategoria Zagłady w szkolnym dyskursie polonistycznym po roku 2009 (na przykładzie prozy Idy Fink i Irit Amiel). Rozprawa doktorska napisana pod kierunkiem prof. dra hab. Sławomira Jacka Żurka (promotor) i dra Piotra Trojańskiego (promotor pomocniczy). Lublin 2017, s. 48 (maszynopis).

${ }^{8}$ Rozporządzenie Ministra Edukacji Narodowej z dnia 15 lutego 1999 r. w sprawie podstawy programowej kształcenia ogólnego. „Dziennik Ustaw Rzeczypospolitej Polskiej” 1999, nr 14, poz. 129. 
i szkole ponadgimnazjalnej. Na lekcjach historii w gimnazjum temat Zagłady pojawiał się w kontekście omawiania zagadnień: „eksterminacja narodów na terenach okupowanych; obozy koncentracyjne i łagry; Holocaust" (Rozporządzenie MEN z dn. 15 lutego 1999 roku), zaś na lekcjach języka polskiego na etapie III uczniowie mieliby poznawać takie teksty, jak: Kamienie na szaniec Aleksandra Kamińskiego, we fragmentach Pamiętnik $z$ powstania warszawskiego Mirona Białoszewskiego oraz poezję Krzysztofa Kamila Baczyńskiego. Na IV etapie edukacyjnym na lekcjach języka polskiego nie wprowadzono zmian - zaproponowano do omówienia opowiadania Borowskiego. Również na lekcjach historii miały pojawiać się informacje na temat „II wojna światowa - geneza; charakter wojny; Holokaust" (Rozporządzenie MEN z dn. 15 lutego 1999 roku).

Furtkę dla wprowadzania nowych treści stanowiło natomiast uwolnienie rynku podręczników. Wspomniana już Kasperek zauważyła:

W roku 1999 przy okazji zmian struktury polskiego szkolnictwa na rynku wydawniczym obserwowano lawinowy wzrost liczby dostępnych podręczników, do wyboru pozostawało około 110 pozycji do nauki języka polskiego w różnych klasach gimnazjalnych. Tematyka Zagłady na III etapie edukacyjnym w większości serii wydawniczych pojawiała się w trzeciej klasie, choć znalazły się wyjątki, gdzie temat ten podejmowano już w klasie drugiej'

Z kolei na poziomie liceum dopuszczonych do użytku od 1999 roku zostało 117 podręczników. Większość z nich poruszała zagadnienie Zagłady w klasie trzeciej. To właśnie wtedy w podręczniku Zrozumieć tekst - zrozumieć człowieka... po raz pierwszy wymieniono $\mathrm{z}$ imienia i nazwiska Idę Fink. Mianowicie, na stronach 125-126 autorzy (D. Chemperek, A. Kalbarczyk, D. Trześniowski) zamieścili miniprzewodnik po literaturze Holokaustu oraz wymienili jej autorów, między innymi: Idę Fink, Irit Amiel, Hannę Krall, Zofię Nałkowską, Henryka Grynberga czy Imrego Kertésza ${ }^{10}$.

Należne jej miejsce w szkolnej edukacji zdobyła Ida Fink dopiero w 2008 roku. Wtedy to, 23 grudnia, ówczesna minister edukacji narodowej Katarzyna Hall podpisała rozporządzenie w sprawie podstawy programowej wychowania przedszkolnego i kształcenia ogólnego w poszczególnych typach szkół, które zmieniło dotychczasowy kształt polskiej edukacji. Dokument zaczął obowiązywać od roku szkolnego 2009/2010 i stopniowo wprowadzano go na wszystkich etapach edukacyjnych. Tematyka Holokaustu pojawiała się w podstawie programowej dwukrotnie $\mathrm{w}$ kontekście lekcji języka polskiego - w gimnazjum i szkole ponadgimnazjalnej. Akt ten na III etapie edukacyjnym utrzymywał teksty, które wymieniono już we wcześniejszych dokumentach: Kamienie na

9 A. KAsperek: Kategoria Zagłady..., s. 65.

10 Zob. D. Chemperek, A. Kalbarczyk, D. Trześniowski: Zrozumieć tekst - zrozumieć człowieka... Cz. 3. Warszawa 1999, s. 125-126. 
szaniec Aleksandra Kamińskiego i Pamiętnik z powstania warszawskiego Mirona Białoszewskiego. Elementem nowym był zapis wprowadzający na lekcje języka polskiego opowiadania autorstwa Idy Fink poruszające problematykę Holokaustu ${ }^{11}$. Z kolei na poziomie podstawowym $\mathrm{w}$ liceum jako novum pojawiło się opowiadanie z tomu Osmaleni Irit Amiel, a na poziomie rozszerzonym między innymi wybrany reportaż Hanny Krall lub Henryka Grynberga.

W 2008 roku nazwisko Idy Fink znalazło się zatem wreszcie w dokumencie urzędowym i odtąd jej obecności nie można było ignorować. Jak podkreślał Krzysztof Biedrzycki w komentarzu do podstawy:

[...] istotne jest, by ukazać uczniowi tragedię Holokaustu: zaproponowane zostało wybrane opowiadanie Idy Fink, gdyż groza jest przez tę autorkę ukazana w sposób na tyle dyskretny, że nie ma w nich [sic!] takiej dawki okrucieństwa i zła, która byłaby zbyt trudna w odbiorze dla uczniów w wieku gimnazjalnym. Zarazem jednak jej utwory oddają istotę tego, co się zdarzyło ${ }^{12}$.

Widomym efektem było przedrukowywanie utworów Fink w gimnazjalnych podręcznikach. Dokładnego ich omówienia pod kątem kształcenia umiejętności uwzględnionych w podstawie programowej dokonała Agnieszka Kasperek ${ }^{13}$. Ja zauważę tylko - $\mathrm{w}$ formie podsumowania - że spośród 18 przeanalizowanych przez badaczkę książek opowiadania Idy Fink nie pojawiły się w żadnej części podręczników: Nasz wspólny świat, którego wydawcą był Wiking, serii Język polski. Podręcznik dla gimnazjum, której wydawcą był Operon, To lubię! Wydawnictwa Edukacyjnego, Czas na polski Oficyny Edukacyjnej Krzysztofa Pazdro oraz Klucze do kultury Wydawnictwa MAC. Utwór Drzazga wykorzystał Witold Bobiński w podręczniku Świat w stowach i obrazach (WSiP), opowiadanie $W a-$ riat natomiast autorki książki Po polsku. Literatura, język, komunikacja z Wydawnictwa Szkolnego PWN ${ }^{14}$, z kolei Wesoła Zosię autorzy Przygód z czytaniem Wydawnictwa $\mathrm{MAC}^{15}$. Zabawa $w$ klucz znalazła się w serii Bliżej słowa WSIP-u ${ }^{16}$

${ }^{11}$ Zob. Podstawa programowa $z$ komentarzami. T. 2: Język polski w szkole podstawowej, gimnazjum i liceum. Warszawa 2009, s. 279.

${ }^{12}$ K. BiedrzycKi: Język polski w gimnazjum - wskazówki metodyczne. W: Podstawa programowa $z$ komentarzami..., s. 79.

${ }^{13}$ Zob. A. Kasperek: Opowiadania Idy Fink - nowość na lekcjach języka polskiego w gimnazjum. W: Auschwitz i Holokaust. Edukacja w szkole i w miejscu pamięci..., s. 101-110; TAż: Badanie obecności literatury polskiej powstałej w Izraelu na lekcjach języka polskiego - uwagi badacza. W: Młoda dydaktyka polonistyczna. Red. M. Fota, A. Porє̨вA, S.J. Żurek. Lublin 2014, s. 105-114.

${ }^{14}$ L. Adrabińska-PacuŁa, A. Hącia, J. Malczewska, J. Olech: Po polsku. Literatura, język, komunikacja. Podręcznik do języka polskiego dla gimnazjum. Klasa III. Warszawa 2011.

15 J. Detкk, M. Jas, P. ZвróG: Przygoda z czytaniem. Podręcznik do kształcenia literacko-kulturowego. Klasa 3. Kielce 2011.

${ }^{16}$ E. Horwath, G. KieŁB: Bliżej słowa. Podręcznik. Klasa 3. Warszawa 2010, s. 296-300. 
oraz serii Między nami Gdańskiego Wydawnictwa Oświatowego ${ }^{17}$, fragmenty Skrawka czasu zaś wykorzystali autorzy Słów na czasie z Nowej Ery ${ }^{18}$, gdzie znalazły się też takie rewelacje, jak: Fink była „ukraińską pisarką żydowskiego pochodzenia, piszącą po polsku” lub „jest autorką zbioru opowiadań Podróż” (w rzeczywistości powieści autobiograficznej) ${ }^{19}$. Jedynie autorki podręcznika Między nami ${ }^{20}$ zdecydowały się oprócz Zabawy w klucz na zamieszczenie jeszcze drugiego opowiadania - Ślad.

\section{Zabawa $w$ klucz na maturze z 2005 roku}

W zasadzie szkolną „obecność” Idy Fink zainaugurowało jednak wydarzenie nieco wcześniejsze. Było to dość niespodziewane pojawienie się Zabawy w klucz na „nowej maturze” w 2005 roku. Przypomnę tylko, że chodzi o państwowy egzamin wprowadzony w całym kraju na mocy reformy oświaty zapoczątkowanej w 1999 roku. Pierwotnie mieli go zdawać absolwenci szkół średnich już w 2002 roku, ale w wyniku rozmaitych nieścisłości w ustawie i związanych z tym kontrowersji ówczesna minister edukacji narodowej i sportu Krystyna Łybacka przesunęła "nową maturę” na 2005 rok, a uczniowie zdający egzamin w 2002 roku mogli wybierać pomiędzy „starą” i „nową” wersją. Począwszy od roku szkolnego 2014/2015, wprowadzono tzw. nową formułę matury z języka polskiego $^{21}$.

Interesujące wnioski można wyciągnąć już z samego zestawu tematów w 2005 roku. Na poziomie podstawowym matury z języka polskiego zaproponowano następujące wypracowania:

${ }_{17}$ A. Łuczak, E. Prylińska: Między nami. Podręcznik do gimnazjum. Język polski 2. Gdańsk 2010.

${ }^{18}$ M. Chmiel, W. Herman, Z. Pomirska, P. Doroszewski: Słowa na czasie. Podręcznik do kształcenia literackiego i kulturowego. Język polski dla klasy trzeciej gimnazjum. Warszawa 2010.

19 Tamże, s. 100.

20 A. Łuczak, E. Prylińska: Między nami. Program nauczania języka polskiego dla trzeciego etapu edukacyjnego (klasy I-III gimnazjum). Gdańsk 2009.

${ }^{21}$ Jest to konsekwencja Rozporządzenia Ministra Edukacji Narodowej z dnia 27 sierpnia 2012 r. w sprawie podstawy programowej wychowania przedszkolnego oraz kształcenia ogólnego w poszczególnych typach szkół („Dziennik Ustaw Rzeczypospolitej Polskiej” 2012, poz. 977), podpisanego przez minister Krystynę Szumilas. Od roku szkolnego 2014/2015 egzamin opiera się właśnie na podstawie programowej (z późniejszymi zmianami), a nie na standardach egzaminacyjnych. Konsekwencją było wydanie rozbudowanego Rozporządzenia Ministra Edukacji Narodowej z dnia 21 grudnia 2016 r. w sprawie szczegółowych warunków i sposobu przeprowadzania egzaminu gimnazjalnego i egzaminu maturalnego („Dziennik Ustaw Rzeczypospolitej Polskiej” 2016, poz. 2223), podpisanego przez minister Annę Zalewską. 
1. Jaki obraz Polaków XVII wieku wyłania się z Potopu Henryka Sienkiewicza. Punktem wyjścia swoich rozważań uczyń wnioski z analizy danych fragmentów powieści. Zwróć uwagę na ich znaczenie dla całości utworu.

2. Analizując wypowiedzi bohaterów romantycznych, porównaj postawę Kordiana i Męża. W interpretacyjnych wnioskach wykorzystaj wiedzę o utworach, $\mathrm{z}$ których pochodzą fragmenty ${ }^{22}$.

Autorzy arkuszy uznali zatem, że do podstawowej wiedzy, jaką ma wykazać się maturzysta, należy kategoria „polskości”, zdający zaś - by zacytować klucz odpowiedzi do tematu nr 1 - musi rozpoznać „złożoność obrazu Polaków w utworze lub naród ukazany w momencie przemiany". To nic, że owa złożoność w przypadku Sienkiewicza - o którym Gombrowicz pisał okrutnie, ale jakże celnie, że był „dostarczycielem przyjemnych snów”23 - jest wysoce wątpliwa, ponieważ próżno szukać w jego tekście na przykład pogłębionych wizerunków postaci Szwedów, niezmiennie pozostających bohaterami negatywnymi, lub kobiet, którym przyznaje się stereotypowe role.

Po napisaniu obowiązkowego zestawu i dostrzeżeniu dwóch postaw bohaterów romantycznych - niezdolności do czynu Kordiana oraz aktywności Męża, czego wymagał temat drugi ${ }^{24}$ - zainteresowani językiem polskim lub podjęciem studiów humanistycznych, a więc znacznie mniej liczni, mogli podejść do poziomu rozszerzonego, na którym przywołana została właśnie Zagłada oraz opowiadanie Idy Fink.

Już pierwszy temat odsyłał do Szoa jako jednego z wielu kontekstów. Temat ów brzmiał: „Analizując i interpretując wiersze Tadeusza Różewicza Ocalony i Józefa Barana Mam dwadzieścia pięć lat, porównaj poetyckie kreacje doświadczeń pokoleniowych i egzystencjalnych”. Egzaminatorzy w kluczu wymienili doświadczenie wojenne Różewicza oraz kluczowe frazy: „furgony porąbanych ludzi” czy „prowadzony na rzeź”. Temat drugi to: „Dokonaj analizy i interpretacji opowiadania Zabawa w klucz Idy Fink, zwracając uwagę na sposób podjęcia tematu zagłady Żydów w czasie II wojny światowej”. Autorzy arkusza sięgnęli więc po twórczość pisarki znanej wówczas słabo, w edukacji szkolnej niemal wtedy nieobecnej.

${ }^{22}$ Wszystkie tematy wypracowań z arkuszy maturalnych oraz wyimki z kluczy odpowiedzi przytaczam za dokumentami dostępnymi na oficjalnej stronie Centralnej Komisji Egzaminacyjnej: http://www.cke.edu.pl/170-egzamin-maturalny.html [data dostępu: 15.05.2013].

${ }^{23}$ W. Gombrowicz: Dziennik 1953-1956. Kraków 1986, s. 352.

${ }^{24}$ Abstrahując już od innego, poważnego problemu, przed jakim stajemy w przypadku przywołanej lektury Nie-Boskiej komedii Zygmunta Krasińskiego, a mianowicie jawnie ksenofobicznego charakteru tego dramatu, który Maria Janion nazwała „arcydziełem skażonym antysemityzmem". Zob. M. JANion: Bohater, spisek, śmierć. Wykłady żydowskie. Warszawa 2009, rozdz. Mit założycielski polskiego antysemityzmu, s. 77-147. 
Komentarza wymaga zawarta w zestawie notka biograficzna:

Ida Fink - ur. w 1921 r. w Zbarażu na Ukrainie; uczyła się we lwowskim konserwatorium. W latach 1941-42 przebywała w getcie; uratowała się, uciekając na aryjską stronę. Od 1957 roku mieszka w Izraelu. Zadebiutowała dopiero jako kobieta blisko 60-letnia, pisząc w języku polskim prawie wyłącznie o doświadczeniach Holocaustu. Opowiadanie Zabawa w klucz pochodzi z jej debiutanckiego zbioru Skrawek czasu z 1987 roku.

Pomijam już fakt, że nawet dla osoby, która zdaje maturę na poziomie rozszerzonym z języka polskiego, a więc dla potencjalnie zainteresowanego przeszłością humanisty, niejasne mogą być określenia „aryjska strona” czy „konserwatorium”. Przede wszystkim jednak notka ta zawiera błędy. Ida Fink nie zadebiutowała wcale „jako kobieta blisko 60-letnia”, gdyż jej opowiadanie Próg ukazało się (pt. Elza, w tłumaczeniu na język francuski) już w 1948 roku w szwajcarskim piśmie „Action”25, wcześniej zaś - choć pod przybranym, aryjskim nazwiskiem - opublikowała w gazetce „Nasz Głos”, która wychodziła w obozie dla dipisów w Ettlingen, okolicznościowy tekst dotyczący obchodów pierwszej rocznicy wybuchu powstania warszawskiego. Z kolei w latach 50. i 60. utwory autorki Odpływającego ogrodu drukowano regularnie w ukazującym się w Izraelu polskojęzycznym tygodniku „Od Nowa”, gdzie także pierwszy raz ukazała się Zabawa $w$ klucz ${ }^{26}$. Wspomniany zbiór opowiadań Skrawek czasu wydano również wcześniej, w 1974 roku, w tłumaczeniu na język hebrajski przez Nachmana Ben Amiego.

Sami maturzyści nie wystraszyli się, a wygłaszane na gorąco komentarze zdających były entuzjastyczne, choć wyrażały też zdziwienie „pojawieniem się na egzaminie rozszerzonym opowiadania Zabawa z kluczem [sic!] Idy Fink":

- Spodziewaliśmy się tematu z Holokaustu. Jednak ta autorka jest nam zupełnie nieznana. Dobrze, że była jej krótka nota biograficzna - opowiadają [zdający - B.K.]. Zdaniem maturzystów z poznańskiego VIII LO im. Adama Mickiewicza egzamin z polskiego na poziomie rozszerzonym był łatwiejszy od podstawowego. - Spodziewaliśmy się na maturze poezji oraz Holokaustu i dokładnie takie tematy się pojawiły. Oba dosyć ciekawe, trudno było się zdecydować, który wybrać - stwierdził Damian Jefremienko ${ }^{27}$.

W sedno problemu trafiła natomiast uczennica V Liceum Ogólnokształcącego w Lublinie, w którym - jak czytamy - „do nieobowiązkowej rozszerzonej części egzaminu przystąpiła znaczna większość zdających”:

\footnotetext{
${ }^{25}$ I. Fink: Elza. Trad. M. Whoch, L. Belleme. «Action» 1948, nº 205.

${ }^{26}$ I. Fink: Zabawa w klucz. „Od Nowa” 1962, nr 44, s. 6.

${ }^{27}$ M. Zubrzycкi: „Potop” bezkonkurencyjny. „Rzeczpospolita” z 6 maja 2005 r., s. 2.
} 
- Nie żałuję. Była prosta - mówiła Monika Siuda. - Trzeba było napisać wypracowanie, do wyboru były dwa tematy: analiza podanych wierszy albo opowiadania pisarki pochodzenia żydowskiego Idy Fink. Wybrałam drugi. Ida Fink opisała historię żydowskiego dziecka, które rodzice podczas wojny uczą, co ma mówić, jak się zachować, gdy do mieszkania zapuka ktoś obcy - „ojciec nie żyje, matka jest w pracy”. Pisałam o dziecku, któremu zabrano dzieciństwo. To był ciekawy temat, ale bałam się cały czas, czy trafię w gusta tych, którzy sprawdzają prace. To trochę irytujące, że na egzaminie decydującym o mojej przyszłości nie mogę pokazać wszystkiego, co umiem, ponieważ efekt może nie pasować do kryteriów, które przyjmą egzaminatorzy ${ }^{28}$.

Na kwestię konieczności dostosowywania odpowiedzi do klucza oraz związane $\mathrm{z}$ tym tłumienie indywidualnych poglądów uczniów od początku zwracali uwagę krytycy „nowej matury”. Tutaj ujawnił się jednak problem jeszcze większy. Otóż okazało się, że zarówno w przypadku tematu pierwszego, gdzie można byłoby to tłumaczyć uniwersalnym wymiarem obu wierszy, jak i - zwłaszcza tematu drugiego w odpowiedzi nie trzeba było wcale odwoływać się do Zagłady i kompletnie lekceważąc kontekst historyczny, można było uzyskać całkiem przyzwoity rezultat oraz otrzymać wiele punktów. Tak zresztą często się działo. Klucz punktował bowiem przede wszystkim formalne aspekty wypowiedzi. Na przykład we wstępnym rozpoznaniu całości ważniejsze było zauważenie, że fabuła jest „silnie udramatyzowana”, opowiadanie ma „wyraźnie zarysowaną kompozycję zamkniętą (wstęp, zawiązanie akcji i jej rozwinięcie, punkt kulminacyjny i puenta)”, narrator zaś jest autorski, „3. os., wszechwiedzący, poza światem przedstawionym, skupiony na opisie zachowań, nie "wnętrza postaci«", niż rozważenie fundamentalnej dla tego utworu problematyki, tj. Holokaustu. Również dalsze części klucza wymieniają konieczność analizy i interpretacji ogólnych kategorii: czasu akcji, przestrzeni, bohaterów czy słowa „zabawa”, jedynie marginalnie przywołując zasadniczy temat tego tekstu - uniwersum Zagłady.

Wniosek, jaki płynął z analizy tego pierwszego, nowego arkusza maturalnego oraz dołączonego do niego klucza, był więc taki, że Szoa stała się na poziomie rozszerzonym matury z języka polskiego jedynie pretekstem i zastąpiona mogła być dowolnym innym tematem. Nie on bowiem okazał się ważny, lecz konstrukcja cytowanego tekstu. $\mathrm{Na}$ tym aspekcie skoncentrowano się także w podsumowaniach tej matury i o szkolenie maturzystów w tym kierunku apelowano. Zdaniem autorów Raportu dotyczącego wyników egzaminu maturalnego $z$ języka polskiego przeprowadzonego $w$ sesji wiosennej 2005 roku ${ }^{29}$ nie stanowiło

${ }^{28}$ P. ReszKa: Nowa nie taka straszna. „Gazeta Wyborcza” z 6 maja 2005 r. [dodatek: „Lublin”], s. 3.

${ }_{29}$ Zob. Raport dotyczący wyników egzaminu maturalnego z języka polskiego przeprowadzonego w sesji wiosennej 2005 roku. Łódź 2005, s. 78. Dostępne w Internecie: http://www.oke.lodz. $\mathrm{pl} /$ pobierz/matura/raporty/jezyk_polski.pdf [data dostępu: 24.04.2020]. 
problemu to, że uczniowie mogli zupełnie pominąć kontekst historyczny, lecz to, że nie posiadali odpowiedniej wiedzy z zakresu poetyki. To tę ostatnią więc postanowiono w najbliższych latach pogłębiać.

\section{Przed lustrem na maturze z 2012 roku}

Potwierdzeniem tego jest analogiczna forma matury na poziomie rozszerzonym z 2012 roku. Po raz kolejny na poziomie podstawowym uczniowie zostali skonfrontowani z tematami niezwykle stereotypowymi:

1. Wyjaśnij symbolikę lewej i prawej strony oraz jej znaczenie dla wymowy utworu, analizując przytoczony fragment III części Dziadów Adama Mickiewicza. Zwróć uwagę na postać Nowosilcowa i postawy innych bohaterów wobec niego.

2. Porównaj postawy życiowe Izabeli Łęckiej i Joanny Podborskiej ukazane w podanych fragmentach Lalki Bolesława Prusa i Ludzi bezdomnych Stefana Żeromskiego. Odwołując się do znajomości utworów, zwróć uwagę na okoliczności, które miały wpływ na ukształtowanie osobowości bohaterek.

Dopiero w wersji rozszerzonej przywołano tematykę współczesną, lecz jedynie w drugim temacie (pierwszy dotyczył obrazu ludzkiego życia na podstawie wierszy $O$ żywocie ludzkim Jana Kochanowskiego oraz Kolęda z pretensjami Agnieszki Osieckiej). Brzmiał on: „Codzienność w czasach Zagłady. Analizując i interpretując opowiadanie Idy Fink Przed lustrem, zwróć uwagę na kreację bohaterek, ich sytuację oraz znaczenie tytułowego lustra".

Przede wszystkim należy zauważyć, że nie skorygowano notki biograficznej Idy Fink, z której znów dowiadujemy się, że pisarka „zadebiutowała dopiero jako kobieta 60-letnia”. Zdobyto się jedynie na skróty, pomijając na przykład epizod z konserwatorium. Nadal jednak wskazywano, że Fink „w latach 1941-42 przebywała w getcie; uratowała się, uciekając na aryjską stronę"30.

Po raz kolejny maturzyści byli optymistami:

- Nie lubię mówić, jak poszło tuż po egzaminie, bo nie chcę się potem rozczarować, ale jestem dobrej myśli. Pisałam kiedyś podobne wypracowanie dotyczące twórczości Idy Fink, więc wybrałam właśnie ten temat. Interesuje mnie czas wojny i okres powojenny - opowiada Iga Winczkiewicz z VI LO im. Jana

${ }^{30}$ Nawiasem mówiąc, ucieczka pisarki na „aryjską stronę" dalece odbiegała od tego, co znamy z innych tekstów należących do literatury świadectwa. Fink nie przebywała bowiem w kryjówkach w mieście czy na wsi, lecz dobrowolnie wyjechała wraz z siostrą na roboty do Niemiec jako Polka. Swoje perypetie opisała później w autobiograficznej powieści Podróż (Londyn 1990). 
Kochanowskiego [w Radomiu - B.K.]. Dziewczyna dodaje, że wybiera się na studia humanistyczne na Uniwersytet Warszawski. O trudnej rzeczywistości w czasach Zagłady pisała też Sofia Ganin. - Tematy nie były trudne, myślę, że sobie poradziłam. Na studia wybieram się do Poznania, ale nie chcę zdradzać na co, żeby nie zapeszyć, mówi maturzystka. Luiza i Paulina są zdecydowane na studia prawnicze w Warszawie. Matura ich zdaniem była jak do tej pory prosta. - Ale klucz do rozwiązań może okazać się zaskakujący, więc cierpliwie poczekamy na wyniki - mówią dziewczyny ${ }^{31}$.

Klucz nie okazał się zaskakujący. Premiował dokładnie to samo, co w przypadku poprzednich rozszerzonych egzaminów maturalnych z języka polskiego. We wstępnym rozpoznaniu najpierw wymieniona została zatem „szczątkowa akcja” opowiadania i „zwykłe, codzienne wydarzenie”, dopiero na końcu zaś problem przedstawienia Zagłady. Dalej wymagane było wskazanie na sytuację bohaterek, tj.:

a. interpretacja słów „od roku wszyscy byli bliskimi sąsiadami”,

b. trudne warunki życia,

c. przymus ciężkiej fizycznej pracy,

d. konieczność wyprzedawania rzeczy, aby przeżyć,

e. wyniszczenie fizyczne jako konsekwencja warunków życia,

f. śmierć najbliższych jako bolesne doświadczenie,

g. zagrożenie własnego życia.

Zauważmy, iż wszystkie te elementy zostały opisane tak ogólnie, że po raz kolejny odsunięto zasadniczy problem kontekstu historycznego. Następnie zdający powinni - według klucza - przyjrzeć się kreacji protagonistek oraz symbolice lustra. Jedynie w podsumowaniu maturzysta miał za zadanie „wskazanie różnic w postawach bohaterek wobec codziennej rzeczywistości czasu Holocaustu oraz dostrzeżenie związku między obrazem czasu Zagłady a środkami jego kreowania”. Gdyby jednak tego nie zrobił, tracił jedynie 3 z łącznie 26 punktów przyznawanych za rozwinięcie (uczniowie otrzymują też po 2 punkty za kompozycję, styl i zapis oraz 8 punktów za język - w sumie 40 punktów). Szoa znów okazała się więc pretekstem do sprawdzenia umiejętności warsztatowych maturzystów.

Co ciekawe, temat dotyczący Holokaustu pojawił się również w 2010 roku na egzaminie maturalnym z języka polskiego na poziomie podstawowym, a zatem tym, który jest obowiązkowy dla wszystkich. Pierwszy z tematów w arkuszu dotyczył Świętoszka Moliera, a ściślej charakterystyki głównego bohatera i postaw innych postaci, drugi zaś brzmiał: „Na podstawie podanego fragmentu utworu

${ }^{31}$ K.M. Wiśniewska, AK: Łatwy egzamin z polskiego. „Gazeta Wyborcza” z 8 maja 2012 r. [dodatek: „Radom”], s. 27. 
Hanny Krall Zdą̇yć przed Panem Bogiem przedstaw przemyślenia Marka Edelmana o możliwościach godnego życia w czasach Zagłady i różnych poglądach na temat godnej śmierci".

Paradoksalnie egzamin na poziomie podstawowym $\mathrm{w}$ znacznie wyższym stopniu odnosił się do samego Holokaustu. O ile wstępna analiza fragmentu wymagała rozpoznania gatunku, opisu bohatera i dostrzeżenia retrospektywności relacji Krall, o tyle pierwszy punkt rozwinięcia dotyczył właśnie „przedstawienia kontekstu historycznego (czas Zagłady), kształtującego postawę i przemyślenia Marka Edelmana". Wśród możliwych odpowiedzi wymienione zostały:
a. łapanki, aresztowania, więzienie,
b. Umschlagplatz, Żydzi idący do wagonów,
c. groza masowej śmierci (komory gazowe, strzelanie do tłumu),
d. upokorzenie Żydów,
e. bezsilność Żydów,
f. bezkarność Niemców,
g. obojętność świata,
h. samotność ginących.

Wprawdzie następne kryteria dotyczyły już kategorii ogólnych (prezentacji przemyśleń Edelmana na temat godnego życia i śmierci oraz bohaterstwa), jednak uwzględnienie obudowy historycznej tego tekstu sprawiło, że egzamin na poziomie podstawowym $\mathrm{w}$ większym stopniu niż matura $\mathrm{z}$ języka polskiego na poziomie rozszerzonym respektował stosowność ujęcia tematu Szoa. W przypadku wersji rozszerzonej mógł on zostać zastąpiony dowolnym innym, istotna okazała się wyłącznie strukturalna umiejętność rozbioru tekstu.

\section{Nowa formuła}

Ten mankament usunięto w tzw. nowej formule matury, od roku szkolnego 2014/2015, kiedy to na egzaminie na poziomie podstawowym obok części testowej wprowadzono również rozprawkę lub interpretację utworu poetyckiego, „rozluźniono" klucz, zastępując go umiejętnościami między innymi sformulowania i uzasadnienia stanowiska wobec problemu podanego $\mathrm{w}$ poleceniu, a także wprowadzono zapis - postrach maturzystów: „pojawienie się rzeczowego błędu kardynalnego dyskwalifikuje pracę - zdający otrzymuje 0 punktów", co uniemożliwiało mylenie kontekstu. W latach 2015-2018 żaden temat na maturze podstawowej czy rozszerzonej nie dotyczył jednak bezpośrednio czasów drugiej wojny światowej (na przykład na maturze na poziomie rozszerzonym w 2015 roku w tzw. interpretacji porównawczej pojawił się motyw zesłania na 
Sybir), choć uczniowie mogli do niej nawiązywać, przywołując inne teksty kultury czy literackie.

Oddzielną kwestią jest obecność twórczości Idy Fink i tematyki Zagłady na maturze ustnej. Prezentacje dotyczące Holokaustu - co potwierdzała moja praktyka szkolna i głosy innych nauczycieli, z którymi rozmawiałem - były chętnie wybierane i realizowane przez maturzystów, dawały im pole do popisu. Abstrahuję od wszystkich kontrowersji związanych z poprzednią, obowiązującą do 2014 roku formułą matury ustnej z języka polskiego, tj. przede wszystkim od kwestii kupowania prezentacji oraz nagminnego przygotowywania ich na korepetycjach. Wspomniane patologie doprowadziły do rezygnacji Ministerstwa Edukacji Narodowej z tej formy egzaminowania. Jak można było przeczytać w oficjalnym oświadczeniu:

W 2015 r. wrócą staromodne zestawy pytań. Uczeń będzie losował pytania i fragment tekstu literackiego, na przygotowanie odpowiedzi dostanie kwadrans, na odpowiedź 10 min plus 5 min na dyskusję z komisją. W komisji zasiądą nauczyciele z jego szkoły. Sprawdzać będą jednak nie twardą wiedzę, czy wykute fakty, ale jak podaje MEN: „umiejętność tworzenia wypowiedzi na określony temat inspirowanej tekstem kultury. W formie monologowej i dialogowej"32.

Od kilku lat więc uczniowie zdają ustną maturę na nowych zasadach. To, czy w pytaniach egzaminacyjnych wykorzystywana jest twórczość Idy Fink oraz jak często w ogóle pojawia się temat Zagłady, wymagałoby oddzielnego zbadania. Zdający mogą na przykład nawiązywać do utworów pisarki - podobnie jak na części pisemnej - podczas konstruowania swoich wypowiedzi i odwoływania się do „innych tekstów literackich” lub „tekstów kultury”. W chwili, kiedy piszę te słowa, nie wiemy jeszcze, jak będzie wyglądał egzamin maturalny dla roczników, które trafiły do szkół średnich od września 2019 roku i kształcą się w nowym, czteroletnim (dla liceum) lub pięcioletnim (technikum) systemie.

\section{Nadchodzi nowe}

Rok 2018 przyniósł wraz z reformą nową podstawę programową. Wielokrotnie podnoszono, że lista lektur jest anachroniczna i przeładowana, w związku z czym zmieniono ją, usuwając różne pozycje lub zastępując je innymi. Jedną z ofiar reformy stała się również Ida Fink. Na liście lektur obowiązkowych dla klas

${ }^{32}$ A. PezDa: Od 2015 roku matura będzie bez prezentacji. "Gazeta Wyborcza” z 28 czerwca 2012 r., s. 3. 
siódmej i ósmej w szkole podstawowej znaleźć można za to między innymi Ziele na kraterze (fragmenty) oraz Tędy i owędy (wybrany reportaż) Melchiora Wańkowicza, wśród lektur uzupełniających zaś Wspomnienia wojenne 22 IX 19395 IV 1945 Karoliny Lanckorońskiej oraz Przekroczyć próg nadziei Jana Pawła II. Podobnie w liceum - w spisie lektur obowiązkowych ostały się opowiadania Tadeusza Borowskiego, Prosze państwa do gazu oraz Ludzie, którzy szli, a także Zdązyć przed Panem Bogiem Hanny Krall, za to dołożono na przykład fragmenty Drogi donikąd Józefa Mackiewicza. Jedynie wśród lektur uzupełniających znaleźć można Przy torze kolejowym (z tomu Medaliony) Zofii Nałkowskiej.

Wygląda więc na to, że Zagłada po raz kolejny stała się w programie „elementem niepożądanym”. Wzięta też została pod uwagę wyrażona przed dziesięciu laty opinia redaktora dwumiesięcznika „Arcana” Jana Filipa Staniłki. Kiedy w 2009 roku wprowadzono twórczość polsko-żydowskich pisarzy zagładowych do podstawy, pisał:

Profesor Żurek umieścił w kanonie wiele pozycji autorów żydowskiego pochodzenia, jednak dziwnym trafem wybór ten wyraźnie wskazuje, iż postrzega on tę spuściznę wyłącznie z perspektywy Holokaustu. Dominują zatem pośledni autorzy współcześni piszący o zagładzie: Ida Fink, Henryk Grynberg czy bliżej mi nieznana Irit Amiel (choć jest już przecież świetny Tadeusz Borowski). Zabrakło za to odważnej decyzji włączenia świadectw wielusetletniej obecności Żydów w Rzeczypospolitej [...] Oby zatem za kilka dekad cała wiedza uczniów o polskich Żydach nie została zredukowana do obarczania za ich zagładę brzydkich nazistów i posłusznych im Polaków. Wyraźnie widać, że cały kanon jest kanonem politycznej poprawności ${ }^{33}$.

Analiza najnowszej podstawy programowej, zwłaszcza z historii, gdzie wyeksponowany został punkt: uczeń „przedstawia i omawia działania rządu Rzeczypospolitej Polskiej wobec tragedii Zagłady, z uwzględnieniem misji Jana Karskiego i roli "Żegoty«"34, a dodatkowo zawarto zapis:

[...] ważne jest, aby w procesie nauczania wykorzystywać, w miarę możliwości, takie formy upamiętniania kluczowych wydarzeń historycznych, jak wycieczki do miejsc pamięci i muzeów, w tym: Muzeum Powstania Warszawskiego, Państwowego Muzeum Auschwitz-Birkenau w Oświęcimiu, Polskiego Cmentarza Wojennego w Katyniu, Muzeum Polaków Ratujących Żydów podczas II wojny światowej im. Rodziny Ulmów w Markowej, Cmentarza Powązkowskiego w Warszawie, Cmentarza Obrońców Lwowa ${ }^{35}$,

${ }^{33}$ J.F. SтANiєко: Kanon poprawnie politycznych lektur. „Rzeczpospolita” z 22 stycznia 2009 r., s. 8 .

${ }^{34}$ Rozporządzenie Ministra Edukacji Narodowej z dnia 30 stycznia 2018 r. w sprawie podstawy programowej kształcenia ogólnego dla liceum ogólnokształcącego, technikum oraz branżowej szkoły II stopnia. „Dziennik Ustaw Rzeczypospolitej Polskiej” 2018, poz. 467, s. 130.

35 Tamże, s. 136. 
zmusza do konkluzji, że obawy Staniłki z 2009 roku zostały w pełni rozwiane. Gwarancją jest „odpowiednie” projektowanie zagadnień, jakimi powinniśmy się jako nauczyciele zajmować przy okazji omawiania polskich reakcji na Szoa, które można podsumować następująco: dobre postawy - tak, negatywne - nie. W nowej podstawie programowej wiedza uczniów o polskich Żydach z pewnością nie została zredukowana do „obarczania za ich zagładę brzydkich nazistów i posłusznych im Polaków", gdyż ci ostatni byli przecież zawsze prawi i szlachetni.

\section{Bibliografia}

Adamczyк-Garbowska M.: Pisarze $z$ „innej” Europy - kilka uwag o recepcji literatury polsko-żydowskiej w Stanach Zjednoczonych. W: Literatura polsko-żydowska. Studia i szkice. Red. E. Prokop-Janiec, S. Żurek. Kraków 2011, s. 233-244.

Adrabińska-Pacu£a L., Hącia A., Malczewska J., Olech J.: Po polsku. Literatura, język, komunikacja. Podręcznik do języka polskiego dla gimnazjum. Klasa III. Warszawa 2011.

BiedRZYCKi K.: Język polski w gimnazjum - wskazówki metodyczne. W: Podstawa programowa z komentarzami. T. 2: Język polski w szkole podstawowej, gimnazjum i liceum. Warszawa 2009.

Chemperek D., Kalbarczyk A., Trześniowski D.: Zrozumieć tekst - zrozumieć człowieka... Cz. 3. Warszawa 1999.

Chmiel M., Herman W., Pomirska Z., Doroszewski P.: Słowa na czasie. Podręcznik do kształcenia literackiego i kulturowego. Język polski dla klasy trzeciej gimnazjum. Warszawa 2010.

Detra J., Jas M., Zвróg P.: Przygoda z czytaniem. Podręcznik do kształcenia literacko-kulturowego. Klasa 3. Kielce 2011.

Famulska-Ciesielska K.: Polacy, Żydzi, Izraelczycy. Tożsamość w literaturze polskiej w Izraelu. Toruń 2008.

Fink I.: Elza. Trad. M. Wloch, L. Belleme. «Action» 1948, nº 205.

Fink I.: Podróż. Londyn 1990.

Fink I.: Zabawa w klucz. „Od Nowa” 1962, nr 44, s. 6.

Gombrowicz W.: Dziennik 1953-1956. Kraków 1986.

Horwath E., KieŁb G.: Bliżej słowa. Podręcznik. Klasa 3. Warszawa 2010.

Janion M.: Bohater, spisek, śmierć. Wykłady żydowskie. Warszawa 2009.

Karolak S.: Doświadczenie Zagłady w literaturze polskiej 1947-1991. Kanon, który nie powstat. Poznań 2014.

KASPEREK A.: Badanie obecności literatury polskiej powstałej w Izraelu na lekcjach języka polskiego - uwagi badacza. W: Młoda dydaktyka polonistyczna. Red. M. FotA, A. PoręBA, S.J. Żurek. Lublin 2014, s. 105-114.

KASPEREK A.: Kategoria Zagłady w szkolnym dyskursie polonistycznym po roku 2009 (na przykładzie prozy Idy Fink i Irit Amiel). Rozprawa doktorska napisana pod kierun- 
kiem prof. dra hab. Sławomira Jacka Żurka (promotor) i dra Piotra Trojańskiego (promotor pomocniczy). Lublin 2017 (maszynopis).

KASPEREK A.: Opowiadania Idy Fink - nowość na lekcjach języka polskiego w gimnazjum. W: Auschwitz i Holokaust. Edukacja w szkole i w miejscu pamięci. Red. P. Trojański. Oświęcim 2014, s. 101-110.

Löw R.: Znaki obecności. O polsko-hebrajskich i polsko-żydowskich związkach literackich. Kraków 1995.

Łuczak A., Prylińska E.: Między nami. Podręcznik do gimnazjum. Język polski 2. Gdańsk 2010.

Łuczak A., Prylińska E.: Między nami. Program nauczania języka polskiego dla trzeciego etapu edukacyjnego (klasy I-III gimnazjum). Gdańsk 2009.

Pezda A.: Od 2015 roku matura będzie bez prezentacji. „Gazeta Wyborcza” z 28 czerwca 2012 r. Dostępne także w Internecie: https://wyborcza.pl/1,75398,12033129,MEN_ogla sza_zasady_nowej_matury__Nie_bedzie_prezentacji.html [data dostępu: 24.04.2020].

Podstawa programowa z komentarzami. T. 2: Język polski w szkole podstawowej, gimnazjum i liceum. Warszawa 2009.

Raport dotyczacy wyników egzaminu maturalnego z języka polskiego przeprowadzonego w sesji wiosennej 2005 roku. Łódź 2005. Dostępne w Internecie: http://www.oke. lodz.pl/pobierz/matura/raporty/jezyk_polski.pdf [data dostępu: 24.04.2020].

ReszKa P.: Nowa nie taka straszna. „Gazeta Wyborcza” z 6 maja 2005 r. [dodatek: „Lublin”]. Dostępne także w Internecie: https://lublin.wyborcza.pl/lublin/1,48724,2692298. html [data dostępu: 24.04.2020].

Rozporządzenie Ministra Edukacji Narodowej z dnia 15 lutego 1999 r. w sprawie podstawy programowej kształcenia ogólnego. „Dziennik Ustaw Rzeczypospolitej Polskiej” 1999, nr 14, poz. 129.

Rozporządzenie Ministra Edukacji Narodowej z dnia 27 sierpnia 2012 r. w sprawie podstawy programowej wychowania przedszkolnego oraz kształcenia ogólnego w poszczególnych typach szkół. „Dziennik Ustaw Rzeczypospolitej Polskiej” 2012, poz. 977.

Rozporządzenie Ministra Edukacji Narodowej z dnia 21 grudnia 2016 r. w sprawie szczegółowych warunków i sposobu przeprowadzania egzaminu gimnazjalnego i egzaminu maturalnego. „Dziennik Ustaw Rzeczypospolitej Polskiej” 2016, poz. 2223.

Rozporządzenie Ministra Edukacji Narodowej z dnia 30 stycznia 2018 r. w sprawie podstawy programowej kształcenia ogólnego dla liceum ogólnokształcącego, technikum oraz branżowej szkoły II stopnia. „Dziennik Ustaw Rzeczypospolitej Polskiej” 2018, poz. 467.

RzĄDCA A.: Foto-Grafie. Fotografische Narrativität im Werk von Ida Fink. München 2012.

SтAnıєко J.F.: Kanon poprawnie politycznych lektur. „Rzeczpospolita” z 22 stycznia 2009 r. Dostępne także w Internecie: https://www.rp.pl/artykul/251805-Kanonpoprawnie-politycznych-lektur.html [data dostępu: 24.04.2020].

Wiśniewska K.M., AK: Łatwy egzamin z polskiego. „Gazeta Wyborcza” z 8 maja 2012 r. [dodatek: „Radom”], s. 27.

Zubrzycki M.: „Potop” bezkonkurencyjny. „Rzeczpospolita” z 6 maja 2005 r., s. 2. 
BARTŁOMIEJ KRUPA - dr, historyk i literaturoznawca, absolwent Uniwersytetu im. A. Mickiewicza w Poznaniu, adiunkt w Instytucie Badań Literackich PAN, a także nauczyciel historii oraz WOS w liceum i technikum. Zajmuje się prozą polską wobec Zagłady, antropologią literatury oraz historią historiografii XX wieku ze szczególnym uwzględnieniem historiografii Holokaustu. Autor książek: Wspomnienia obozowe jako specyficzna odmiana pisarstwa historycznego (2006), Opowiedzieć Zagładę. Polska proza i historiografia wobec Holokaustu (1987-2003) (2013) oraz Spór o Borowskiego (2018). Laureat m.in. nagrody specjalnej „Otwartej Rzeczpospolitej” w Konkursie im. Jana Józefa Lipskiego oraz zdobywca pierwszej nagrody w Konkursie im. Majera Bałabana na najlepsze prace doktorskie o Żydach i Izraelu. Stypendysta Fundacji na rzecz Nauki Polskiej (2008) oraz Narodowego Centrum Nauki (2012-2015). W 2016 roku visiting professor na Uniwersytecie Hebrajskim w Jerozolimie. 